\title{
Indkaldelse af artikelforslag
}

\section{VIRUS}

„En tsunami af virus truer" kan man læse i medierne. COVID-19 har ramt os, og de fleste har fået vendt op og ned på deres liv nærmest fra den ene dag til den anden. Vi følger med, når Statsministeriet indkalder til pressemøde, og vi følger med i dagens coronatal over smittede og døde. Vi lever i et liv i limbo i coronaland, som medierne kalder det. Møder og aftaler er aflyst. Arbejdspladser og skoler er lukket. Håndteringen af smittefaren har medført social isolation, fysisk afstand til andre, håndvask og afspritning, og vi lærer nye ord som smittekæder, værnemidler, coronaansvar og altansang. Gamle og kronisk syge er særligt udsatte. Dronningen kommer på banen og taler til nationen med en opfordring til at udvise ansvarlighed og tage hensyn. Vi ser også, som det ofte sker i samfund under akut stress, at der hamstres, at der er stigende vold mod kvinder og børn, og at presset på krisecentrene øges. Vi lærer dog også hurtigt at omstille os. Gåturen genopdages for manges vedkommende. Vi benytter os af vareudbringning i stigende grad, og vi gør udvidet brug af digitale medier. Vi har undervisning over nettet, holder skærmmøder og sågar selskabelige sammenkomster.

Coronakrisen og smittespredningen viser med al tydelighed, at vi lever i en global verden. Men den viser også, hvordan staten markerer sig i krisetid, og hvordan konkrete stater kan følge forskellige strategier. Grænser lukkes, borgerne kaldes hjem, der gennemføres hastelove og initiativer, lønkompensation og hjælpepakker, der skal ,holde hånden under“ dansk erhvervsliv og økonomi. Usikkerheden i den ellers så kontrollerede og trygge velfærdsstat Danmark er stor og svær for mange - hvornår ,åbnes samfundet op“, hvordan og i hvilken takt? Og hvordan vil fremtiden se ud?

Coronakrisen vil blive genstand for forskning, også antropologisk forskning. Der er allerede forsket en del i usikkerhed i forbindelse med naturkatastrofer som for eksempel tsunamien i 2004, og der er forsket i aids-epidemien fra begyndelsen af 1980'erne. Indsigter fra denne forskningslitteratur kan være relevant at inddrage. Med dette call ønsker vi at få belyst spørgsmål som: Hvad gør coronakrisen ved folk? Hvordan har de erfaret krisen? Hvordan reagerer de på smit- 
tefare og usikkerhed? Hvad gør den ved folks oplevelse af staten som markant aktør? Sker der en aktualisering af „samfundssind“ og nationalfølelse? Hvorfor anlægger de nordiske lande forskellige strategier, og hvilken betydning har det? Hvordan fungerer balancen mellem tvang og frivillighed? Hvordan opleves coronakrisen af folk i lande uden for Vesteuropa? Hvad findes af konspirationsteorier om virussens opståen og udbredelse?

Forslag til artikler (abstract på maksimalt 300 ord) og andre bidrag (enqueter og positioner) sendes til:

tidsskrift.antropologi@anthro.ku.dk senest den 15. september 2020. 